Objectives: Here, we investigated the therapeutic potential of ibrutinib, a Bruton's tyrosine kinase (BTK) inhibitor used in B cell malignancies, to alter B cell pathology in SSc in an in vitro model of autoimmunity.

Methods: PBMCs and sorted B cells of 24 patients with SSc were used for functional testing after stimulation with hypomethylated DNA fragments $(\mathrm{CpG})$ to induce an innate immune response. The effects of ibrutinib on cytokine production, autoantibody release and activation of the transcription factor NFKB were evaluated via multiplex cytokine assay, ELISA and flow cytometry.

Results: Ibrutinib was able to reduce the production of the profibrotic hallmark cytokines IL-6 and TNF-a, which are mainly released by the effector B cell population, in response to TLR9-stimulation. Importantly, small doses of ibrutinib $(0.1 \mu \mathrm{M})$ preserved the production of immunoregulatory IL-10 and IFN- $\gamma$ while effectively inhibiting the cardinal cytokines of hyperactivated profibrotic effector B cells in SSc. Intracellular cytokine staining of IL-6 in B cell subsets further endorsed the potential of ibrutinib to inhibit $B$ cells in a subset-specific manner, reducing IL- $6^{+}$naïve $B$ cells significantly but not IL- $6^{+}$memory B cells. The subset specificity was abolished when high doses of ibrutinib $(10 \mu \mathrm{M})$ were applied. In a flow cytometry analysis of phosphorylated $\mathrm{NFKB}$, an important transcription factor in the induction of innate immune responses in B cells, significantly less activation was observed with ibrutinib treatment $(0.1 \mu \mathrm{M})$. Higher doses of ibrutinib were unable to further reduce the abundance of pNFkB.

Conclusion: Our data could pave the avenue for a clinical application of ibrutinib for patients with SSc as a novel treatment option for the underlying pathogenetic immune imbalance contributing to disease onset and progression.

References:

[1] Khanna, D. et al. Efficacy and Safety of Tocilizumab for the Treatment of Systemic Sclerosis: Results from a Phase 3 Randomized Controlled Trial [abstract]. Arthritis Rheumatol. 2018; 70 (suppl 10).

[2] Jordan, S. et al. Effects and safety of rituximab in systemic sclerosis: an analysis from the European Scleroderma Trial and Research (EUSTAR) group. Ann. Rheum. Dis. 74, 1188-1194 (2015).

Disclosure of Interests: Jakob Einhaus: None declared, Ann-Christin Pecher: None declared, Elisa Asteriti: None declared, Hannes Schmid: None declared, Kathy-Ann Secker: None declared, Silke Duerr-Stoerzer: None declared, Hildegard Keppeler: None declared, Reinhild Klein: None declared, Corina Schneidawind: None declared, Jörg Henes Grant/research support from: Novartis, Roche-Chugai, Consultant of: Novartis, Roche, Celgene, Pfizer, Abbvie, Sanofi, Boehringer-Ingelheim,, Dominik Schneidawind: None declared DOI: 10.1136/annrheumdis-2020-eular.1791

\section{AB0030 INCREASED CIRCULATING CD19+CD24HICD38HI REGULATORY B CELLS ARE BIOMARKERS OF RESPONSE TO METHOTREXATE IN EARLY RHEUMATOID ARTHRITIS}

P. Fortea-Gordo ${ }^{1,2}$, A. Villalba ${ }^{1,2}$, L. Nuño ${ }^{1,2}$, M. J. Santos-Bornez ${ }^{1,2}$ D. Peiteado ${ }^{1,2}$, I. Monjo ${ }^{1,2}$, A. Puig-Kröger ${ }^{3}$, P. Sanchez-Mateos ${ }^{3}$, E. MartínMola ${ }^{2,4}$, A. Balsa ${ }^{1,2}$, M. E. Miranda-Carus ${ }^{1,2}$. ${ }^{1}$ University Hospital La Paz, Rheumatology, Madrid, Spain; ${ }^{2}$ Fundación Para La Investigación Biomedica Del Hospital Universitario La Paz, Madrid, Spain; ${ }^{3}$ Hospital Gregorio Marañón, Immuno-oncology, Madrid, Spain; ${ }^{4} D$-medical, Madrid, Spain

Background: The protagonism of regulatory B cells seems to vary along the course of the disease in murine models of inflammatory conditions. Decreased numbers of circulating regulatory CD19+CD24hiCD38hi transitional B cells (cTrB) have been described in patients with longstanding RA.

Objectives: To examine the frequency and evolution of cTrB cells in the peripheral blood of early RA (ERA) patients.

Methods: Freshly isolated PBMCs from 48 steroid and DMARD-naïve ERA patients with a disease duration below 24 weeks and 48 healthy controls $(\mathrm{HC})$ were examined by flow cytometry. Cocultures of isolated memory B cells were established with autologous T cells, in the absence or presence of TrB cells.

Results: As compared with HC, ERA patients demonstrated an increased frequency of cTrB cells. cTrBs of ERA and HC displayed an anti-inflammatory cytokine profile and were able to downregulate T cell IFN $\gamma$ and IL-21 production, together with ACPA secretion in autologous $\mathrm{B} / \mathrm{T}$ cell cocultures. Basal frequencies of cTrBs above the median value observed in $\mathrm{HC}$ were associated with a good EULAR response to MTX at 12 months $(\mathrm{RR}=2.91 ; 95 \% \mathrm{Cl}, 1.37-6.47)$. A significant reduction of CTrBs was observed 12 months after initiating MTX, when the cTrB cell frequency was no longer elevated but decreased, and this was independent of the degree of clinical response or the intake of prednisone. Conclusion: An increased frequency of regulatory cTrB cells is apparent in untreated ERA, and the baseline cTrB cell frequency is associated with the clinical response to MTX at 12 months.

References:

[1] Matsushita T, et al. J Clin Invest. 2008;118:342. Flores-Borja F, et al. Sci Transl Med. 2013;5:173ra23.
Disclosure of Interests: Paula Fortea-Gordo Grant/research support from: BMS, Alejandro Villalba: None declared, Laura Nuño: None declared, MariaJose Santos-Bornez Grant/research support from: BMS, Diana Peiteado: None declared, Irene Monjo: None declared, Amaya Puig-Kröger: None declared, Paloma Sanchez-Mateos: None declared, Emilio Martín-Mola Grant/research support from: BMS, Roche, Alejandro Balsa Grant/research support from: BMS Roche, Consultant of: AbbVie, Gilead, Lilly, Pfizer, UCB, Sanofi, Sandoz, Speak ers bureau: AbbVie, Lilly, Sanofi, Novartis, Pfizer, UCB, Roche, Nordic, Sandoz, Maria-Eugenia Miranda-Carus Grant/research support from: BMS, Roche DOI: 10.1136/annrheumdis-2020-eular.930

\begin{tabular}{|l|l}
\hline AB0031 & T HELPER 17 CELLS WERE SIGNIFICANTLY \\
DECREASED BY MITOCHONDRIAL ELECTRON \\
TRANSPORT CHAIN COMPLEX INHIBITOR IN \\
PATIENTS WITH RHEUMATOID ARTHRITIS
\end{tabular}

H. R. Lee ${ }^{1,2}$, S. J. Yoo ${ }^{2}$, J. Kim², I. S. Yoo², C. K. Park², S. W. Kang ${ }^{1,2}$ ${ }^{1}$ Chungnam National University, Daejeon, Korea, Rep. of (South Korea); ${ }^{2}$ Chungnam National University Hospital, Daejeon, Korea, Rep. of (South Korea)

Background: Reactive oxygen species (ROS) and T helper 17 (TH17) cells have been known to play an important role in the pathogenesis of rheumatoid arthritis (RA). However, the interrelationship between $\mathrm{ROS}$ and $\mathrm{TH} 17$ remains unclear in RA

Objectives: To explore whether ROS affect TH17 cells in peripheral blood mononuclear cells (PBMC) of RA patients, we analyzed ROS expressions among $T$ cell subsets following treatment with mitochondrial electron transport chain complex inhibitors.

Methods: Blood samples were collected from 40 RA patients and 10 healthy adult volunteers. RA activity was divided according to clinical parameter DAS28. PBMC cells were obtained from the whole blood using lymphocyte separation medium density gradient centrifugation. Following PBMC was stained with Live/Dead stain dye, cells were incubated with antibodies for CD3, CD4 CD8, and CD25. After fixation and permeabilization, samples were stained with antibodies for FoxP3 and IL-17A. MitoSox were used for mitochondrial specific staining.

Results: The frequency of TH17 cells was increased by 4.83 folds in moderate disease activity group (5.1>DAS28 $\geq 3.2)$ of RA patients compared to healthy control. Moderate RA activity patients also showed higher ratio of $\mathrm{TH} 17 / \mathrm{Treg}$ than healthy control (3.57 folds). All RA patients had elevated expression of mitochondrial specific ROS than healthy control. When PBMC cells were treated with $2.5 \mathrm{uM}$ of antimycin A (mitochondrial electron transport chain complex III inhibitor) for $16 \mathrm{~h}$, the frequency of $\mathrm{TH} 17$ cells was significantly decreased.

Conclusion: The mitochondrial electron transport chain complex III inhibitor markedly downregulated the frequency of $\mathrm{TH} 17$ cells in moderate disease activity patients with RA. These findings provide a novel approach to regulate $\mathrm{TH} 17$ function in $\mathrm{RA}$ through mitochondrial metabolism related ROS production.

References:

[1] Szekanecz, Z., et al., New insights in synovial angiogenesis. Joint Bone Spine, 2010. 77(1): p. 13-9.

[2] Prevoo, M.L., et al., Modified disease activity scores that include twentyeight-joint counts. Development and validation in a prospective longitudina study of patients with rheumatoid arthritis. Arthritis Rheum, 1995. 38(1): p. 44-8.

Disclosure of Interests: None declared

DOI: 10.1136/annrheumdis-2020-eular.3441

\section{$\mathrm{AB} 0032$ ABNORMAL STATUSES OF PERIPHERAL CD4+T CELL SUBSETS IN PATIENTS WITH GOUT AND THEIR CHANGES AFTER RECEIVING COMBINED IMMUNOMODULATORY THERAPY}

M. J. Chang ${ }^{1}$, S. X. Zhang ${ }^{2}$, L. Zhao ${ }^{2}$, J. Qiao ${ }^{2}$, J. Zhang ${ }^{2}$, M. T. Qiu ${ }^{2}$, R. Zhao ${ }^{2}$, Y. Li $i^{2}$, C. Wang ${ }^{2}$, J. Luo ${ }^{2}$, G. Y. Liu' ${ }^{2}$ C. Gao ${ }^{3}$ X. Li $^{2}$. ${ }^{1}$ Shanxi Medical University, Taiyuan, China; ${ }^{2}$ The Second Hospital of Shanxi Medical University, Taiyuan, China: ${ }^{3}$ Brigham and Women's Hospital, Harvard Medical School, Boston, United States of America

Background: Gout is a chronic systemic inflammatory disease that results from the deposition of monosodium urate crystals in joints and the associated activation of the innate immune system associated with hyperuricemia ${ }^{1}$. As the pathogenesis of gout is still a matter of speculation and debate, accumulating evidence converges on inflammasome activation and immunological dysregulation $^{2}$. However, the detailed statuses of lymphocyte subsets in patients with gout are unknown and influence of immunomodulatory combination therapies on the lymphocyte subsets remain to be clearly evaluate ${ }^{3}$. 